\title{
下大静脈後尿管のめずらしい一例
}

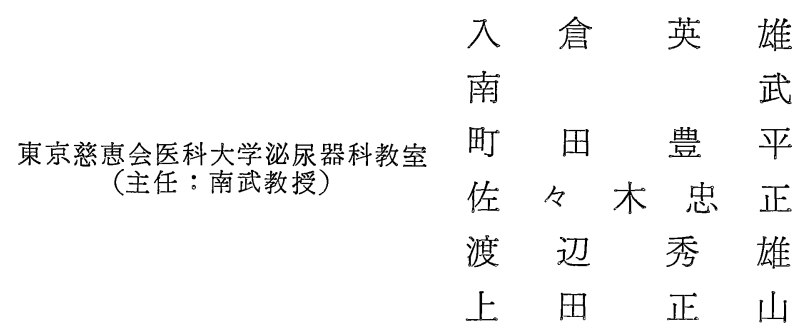

\section{A RARE CASE OF RETROCAVAL URETER}

\author{
Hideo Irikura, Takeshi Minami, Toyohei Machida, Tadamasa Sasaki, \\ Hideo Watanabe and Masataka Ueda \\ The Department of Urology, The Jikei University School of Medicine
}

Huntington and McClure (1920) have described 15 theoretical forms of venous anomaly associated with a retrocaval ureter. Many forms of them have actually been reported. We, however, recently experienced a patient with a form which has not been described in the literature.

K.S., male, aged 49 years. This man visited us with the chief complaint of asymptomatic hematuria in october, 1971. Drip infusion pyelography (DIP) and retrograde pyelography (RP) combined with vena-cavagraphy showed that the right renal pelvis and the upper part of the right ureter were dilated, presenting an S-configuration. The examination also revealed that the vena cava and the right ureter crossed each other at the level of the fourth lumbar vertebra, and the vena cava between the second and third lumbar vertebrae appeared to branch off, with the ureter passing through the branches. In surgery, it was found that the iliac veins on both sides were united into a vena cava over a short length, then branched, and again, directly under the renal vein, were united. And the ureter passed through the ring of vena cava thus formed. Pyeloplasty and pyeloureteroneostomy were performed.

Embryologically, retrocaval ureter is formed when the supracardinal vein shrinksd and the postcardinal vein persists to form the vena cava, or when both the supracardical vein and the postcardical vein persist to form the vena cava. In the latter instance, the ureter posses through the vena cava. The case dealt with in this report is an anomaly that belongs to the latter category. The present case may appear similar to type 2 (Fig. 5) in the classification proposed by Harbach, Nielsen, Campbell, Anderson, etc, but is different in that the iliac veins on both sides are united into one vena cava, which branches off, forms a ring and again is united. This case is considered as an entirely new type of anomaly that does not come under the stated classification.

As a complication, our case suffered from anomalies of intestinal rotation and fixation.

\section{緒言}

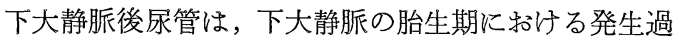
程の異常であり，尿管の奇形というょり静脈の奇形であ る. Hochstetter ${ }^{11)}$ が1893年に剖検例を報告したのが最 初とされている。その後, 上線診断の進歩と共に, 漸 次, 症例は增加し, 最近, Bitker ${ }^{2)}$ (1965) が 140例,
Ber jlan $^{12}$ (1967) か 150例以上を報告し, 本邦では, 教 室の工藤・南（1970）が89例を蒐集し報告している。本 症を発生学的所見から， Harbach ${ }^{10)}$ (1940) は 4 型に, Nielsen ${ }^{20)}$ (1959) は5 型に, Campbell and Anderson ${ }^{5)}$ （1965）は7 型に分類しているが，われわれはかれらの 分類にみられない, 全く新しい型の症例を経験した。 


\section{症例}

患者 勢古口某, 49 才, 男, 会社役員.

初湸昭和 46 年10月 6 日

主訴 無症候性血尿

現病歴 昭和46年 9 月19日，テニスのあとブドウ酒色 の無症候性全血尿が出て, 9月20日某大学病院泌尿器科 受診, 膀胱鏡検查では異常がみられず，Urography で右 水腎・水尿管を指摘された. 血尿は 2 日間の久で, 発熱 や側腹部痛はなかつた。

既往歷 生来胃腸が弱く，昭和26年頃から十二指腸潰 瘍で服薬中.

家族歷 父：心臓弁膜症で50才のとき死亡. 母：腹膜 炎で22才のとき死亡. 同胞はいない.

現症 身長 $175 \mathrm{~cm}$, 体重 $51 \mathrm{~kg}$ でやせ型. 血液型 $B$ 型, $\mathrm{Rh}(+)$. 血圧 $120 / 80 \mathrm{~mm} H \mathrm{Hg}$. 両側腎は触れず. 外性器, 前立腺は正常.

\section{諸検查成績}

1）検尿 全く清澄で, 沈椬に異常なく，培荃でも菌 陰性.

2) 血液検查 $\mathrm{Hct} 43 \%, \mathrm{Hb} 13.1 \mathrm{~g} / \mathrm{dl}$, 白血球数 7400 , 赤血球数 $434 \times 10^{4}$, 出血時間 1 分 30 秒, $\mathrm{Ca}$ 再 加凝固時間 1 分 17 秒, プロトロンビン時間 13.6秒, 85 $\%$.

3）血液化学 総コレステロール $133 \mathrm{mg} / \mathrm{dl}$, 総ビリル ビン $0.7 \mathrm{mg} / \mathrm{dl}$, 直接ビリルビン $0.1 \mathrm{mg} / \mathrm{dl}$, 間接ビリルビ ン $0.6 \mathrm{mg} / \mathrm{dl}$, チモール混濁試験 2.0 単位 $/ \mathrm{ml}$, 尿素窒素 $10.9 \mathrm{mg} / \mathrm{dl}$, クレアチニン $1.0 \mathrm{mg} / \mathrm{dl}, \quad \mathrm{Cl} 109 \mathrm{mEq} / \mathrm{L}, \mathrm{Na}$ $140 \mathrm{mEq} / \mathrm{L}, \mathrm{K} 4.1 \mathrm{mEq} / \mathrm{L}, P 3.7 \mathrm{mg} / \mathrm{dl}$, アルカリフォス ファターゼ 1.5 単位 $/ \mathrm{ml}$, 総酸性フォスファターゼ 0.58 単位 $/ \mathrm{ml}$, 前立腺性酸性フォスファターゼ 0.13 単位 $/ \mathrm{ml}$, GOT 18単位 $/ \mathrm{ml}$, GPT 15単位 $/ \mathrm{ml}$, 乳酸脱水素醭素 138 単位 $/ \mathrm{ml}$.

4）血清沀白分画 正常範囲

5）スパイログラム 正常範围

6）腎機能検查 PSP 試験15分值 25\%，2 時間值65 \%.フィシュバーグ濃縮試験最高 1.034

7） 乙線検査 尿路単純像には結石様陰影等の異常な く, DIPでは右腎は水腎症を呈し，尿管は外側方に向つ て下降し, 水尿管となり, 第 V腰椎部で内方に回転し, 第I腰椎上縁で正常大となつて正中側寄りを下降してい る (第 1 図).このため下大静脈後尿管が疑われ，RP と 下大静脈撮影の併用を行なつた (第 2 図).RP で右尿管 カテーテルは，第腰椎の高さで内方に偏し，腎孟およ
び上部尿管は拡張し，特異な S 字状を描き，DIP と同様 所見であつた，下大静脈撮影法を併用すると，下大静脈 と右尿管は第IV腰椎の高さで交叉し, しかも下大静脈は 第 II 腰椎から第吕腰椎の間が分岥し，その間を尿管が貫 通しているようにみえた。

以上より, 下大静脈後尿管と䛦断し, 昭和 46 年 12 月 1

第 1 図 D I P 20分像で右尿管の拡張と異常走行が みられる。

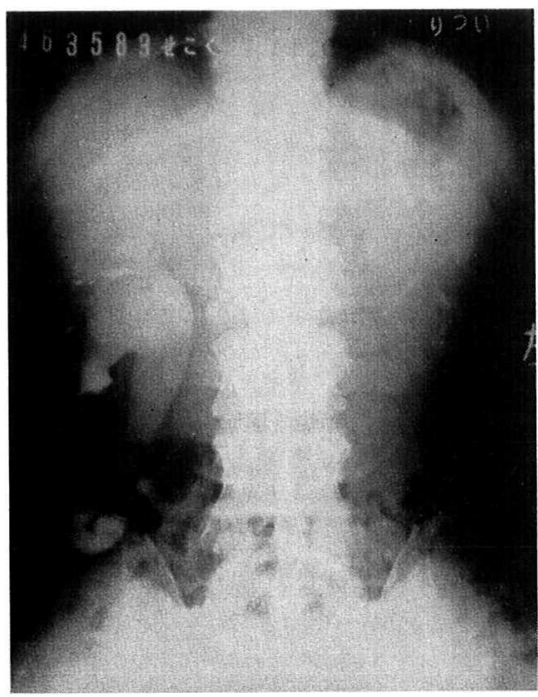

第 2 図下大静脈撮影と右逆行性腎・尿管撮影の併 用. 右腎孟拉よび尿管性拡張し, 特異な $\mathrm{S}$ 字状を描き，乙か子下大静脈は二叉分岥 し，兑の間を尿管が貫通している。

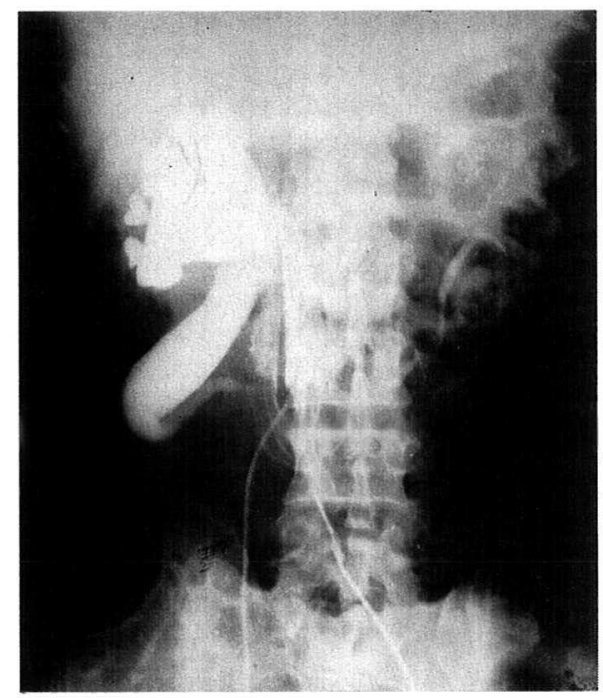


第 3-A図手術時所見 下大静脈が二叉に分岐し， その間を尿管が通つている。

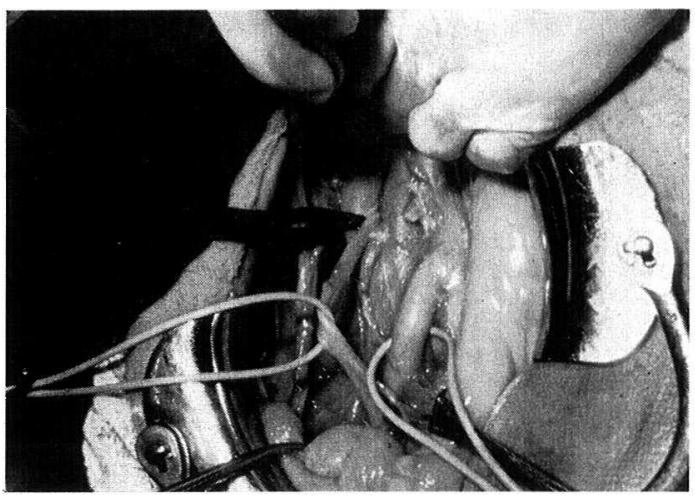

日， GOF 全身麻醉のもとで，経腹膜的に手術を行なつ た.

手術所見 経腹膜的に右腸骨動脈の交叉部で正常大の 尿管を発見. 後腹膜を切開すると尿管は下大静脈の内側 に沿つて走り，第正腰椎部で後方に巻いていた．右腎盘 拉よび上部尿管は著明に拡張して外下方に下降し（約 9 $\mathrm{cm})$ ，さらに鋭角をなして属曲上行し (約 $6 \mathrm{~cm})$,下大静脈 と後方で交叉していた，尿管と下大静脈の関係を確めた ところ下大静脈が二叉に分岐し，その間を尿管が通つて いた.

すなわら，両腸骨静脈が一旦一本の下大静脈となつた あと，すぐ分岐し，（その間を尿管が貫き）婜静脈の直 下で再び一本となつていた．分岐部の下大静脈の長さは $12 \mathrm{~cm}$ で二本の下大静脈直径は中央部で各々 $1.5 \mathrm{~cm}$, 左側 の上方拉よび右側の下方の下大静脈茎は細くなつていた (第 3-A, 3-B).右水腎・水尿管は高度でしか子尿管は延 長していたため，腎盂形成・腎盂尿管吻合術を行なつ た。すず，下大静脈と交叉部で尿管を切断し，拡張した 腎盂尿管部は約 $8 \mathrm{~cm}$ 斜めに切除, 縫縮し, 下方の尿管々 端々吻合した、なお， Fr6スプリントカテーテルを腎瘦 之兼用して尿管に蛙いた。

術後経過 術後熱発はなく順調に経過し， 3 週目スプ リントカテーテルを抜去した。術後42日目の DIP は， まだ水腎所見が残つていたが尿管の走行は正常化してお り，経過観察中である (第 4 図).

\section{考案}

下大静脈後尿管は下大静脈の胎生期における発生異常 で, 尿管の奇形というより,下大静脈の奇形である. 静脈 系の発生に関して Rathke ${ }^{23)}$, Kerschner $^{13)}$, Hochstetter ${ }^{11}$
第 3-B 図手術時所見の図示

$\mathrm{a}$ : 下大静脈 $\mathrm{b}$ : 尿管 $\mathrm{c}$ : 右総腸骨静脈 d : 腸骨動脈

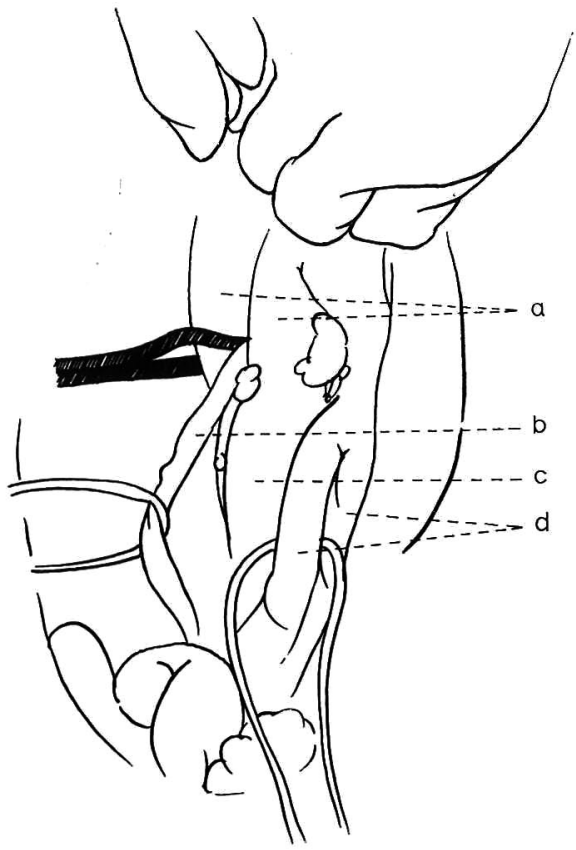

第 4 図術後 42 日目のDI Pまだ水腎所見が残つて いるが尿管走行は正常化している。

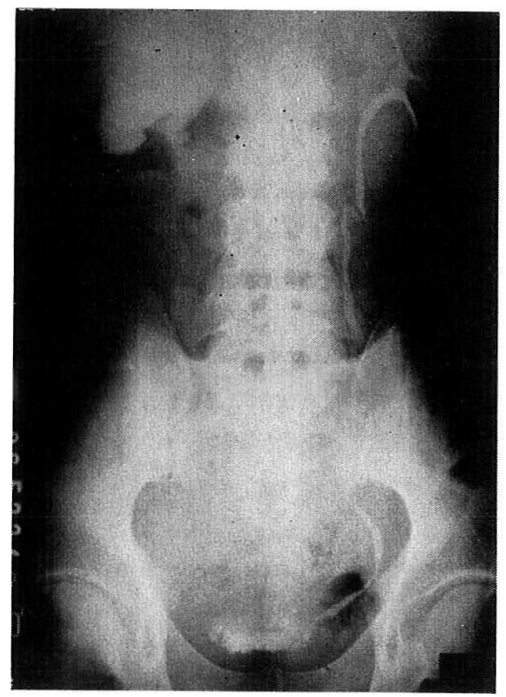


の発表以来, 多くの業績 $\left(\right.$ Lewis $^{15)}$, Huntington ${ }^{12)}$, McClure $^{16) 17)}$, Butler $^{4117)}$, Sabin $^{26)}$, Reagan ${ }^{24) 25)}$ ) が人間户動 物について報告されている。臨床的には Gladstone ${ }^{8)}$, Graves $^{9)}$, Davidoff ${ }^{91}$, Randall ${ }^{22)}$, Campbell ${ }^{22)}$ らによつて 注目されるに至つた.

Huntington \& Mc Clure ${ }^{12)}$ (1920) は理論上，15型の Preureteric inferior vena cava が起こる可能性を指摘し ている. 本症を $\mathrm{Harbach}^{10)}$ (1940) は4 型に, Nielsen ${ }^{20)}$ （1959）は 5 型に, 更に Campbell and Anderson ${ }^{5)}$ (1965) は7 型に分類している. 次に本症の発生学的異常につい て考察してみる.

胎生期早期において，3 刘の静脈系，すなわち Postcardinal Vein, Subcardinal Vein おちよび Supracardinal Vein が左右飞発生する. 胎生25日頃に先ず側方に Postcardinal Vein が発生し, 次いで正中側に Subcardinal Vein, 後方飞 Supracardinal Vein が発生し, これらは 吻合枝によつて, Periureteric ring を形成する。これを Huntington and McClure ${ }^{12)}(1920)$ は "the renal collar" と称した，腎・尿管はこの ring 内を通つて上行し，胎 生第 5 週頃に本来の定位置に達する. その後, 正常の発 生過程では, Supracardinal Vein の左側は消失し, 右側 から下大静脈が形成される. Postcardinal Vein の左側 は完全に消失し, 右側は Azygos Vein となる. Subcardinal Veinは内精索静脈となり, 右側の上部は下大静脈の Suprarenal Segment すなわち，右腎静脈と右 Suprarenal Vein 左側の上部は左腎静脈と左 Suprarenal Vein とな る.上記の関係から，正常の場合は，右尿管は下大静脈 の前に存在することになる. この静脈系の発生退行過程 飞異常がおこると，尿管が下大静脈の背面を廻るように なり，下大静脈後尿管となる。

すなわち, Supracardinal Vein が萎縮し, Postcardinal Vein が残存し下大静脈を形成し，また Supracardinal Vein と Postcardinal Vein が共に残存し下大静脈を形成 した場合（この場合は下大静脈の間を尿管が通るように なる）に本症例となる ${ }^{5) 20221)}$. 自験例では，後者の Supracardinal Vein と Postcardinal Vein が共に残存しな場 合に属する発生異常例である.

Harbach $^{10)}$ (1940) は本症を4 型に分類し, Nielsen ${ }^{20)}$ （1959）は71例の報告例から5 型に分類し，更に Campbell and Anderson ${ }^{5)}$ (1965) は Brooks ${ }^{3)}$ (1962) の完全 内蔵逆位にみられた左側例と Corbus ${ }^{6)}$ (1960) の右腸骨 静脈後尿管を加之 7 型に分類している. 1 型以外は極め て稀である. 自験例とかれらの分類による 2 型との違い
は下大静脈が二叉に分岐し，その間を尿管が通つている 点は同じであるが，自験例では両腸骨静脈が一旦一本の 下大静脈となつたあと，すぐ分岐している．かれらの 2 型は雨腸骨静脈は一本にならないで互に交叉している (第 5 図).

自験例は前記のどの分類にもみられない文献上, 全く 新しい型の症例である.

第 5 図 自験例と 2 型は共に下大静脈が二叉に分岐 し，并の間を尿管が通つているが，自験例 では両腸骨静脈が一旦一本の下大静脈とな つだとすぐ分皮している。2 型は一本に ならないで互に交叉している。

2 型

(Harbach, Nielsen, Campbell 5 )

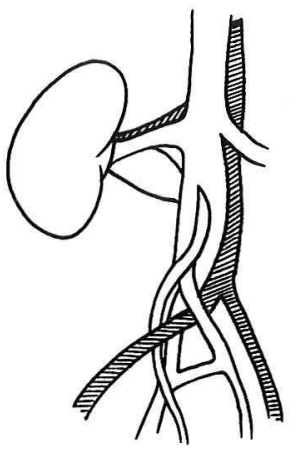

自験例

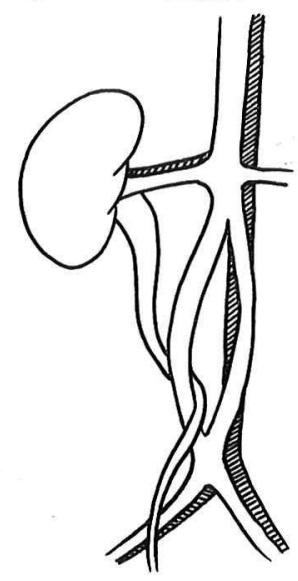

第 6 図 腸回転異常 空腸の位置が変位している.

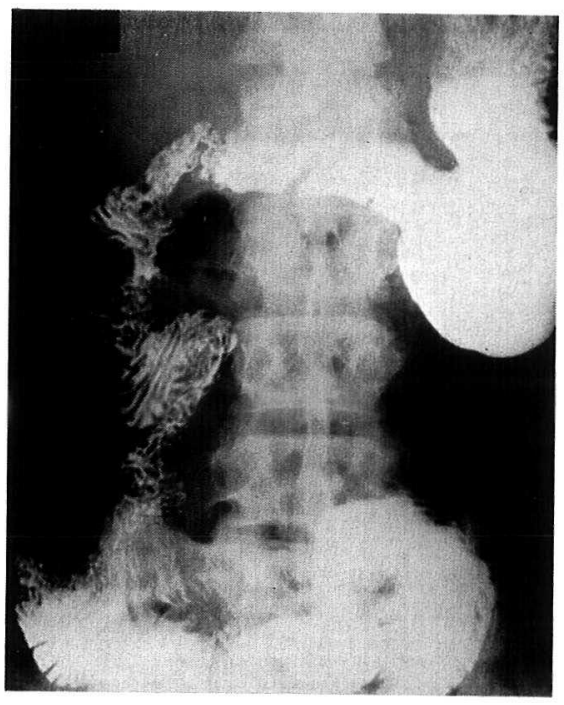


また，本症は身体各所に発生異常を伴つていることが 多い. 自験例では腸回転異常症が 合併していた（第 6 図).本邦では, 工藤・南 ${ }^{14}$ （1970）の89例のうち, 明ら かな奇形合併症は右腎異常血管 ${ }^{19)}$, 尿道下裂 ${ }^{27)}$, 鬼展 ${ }^{28)}$, 多発性囊胞腎" ${ }^{7)}$, 左腎欠損兼右精管欠損 ${ }^{18)}$ の 5 例であ る.

\section{結 語}

1）われわれは最近，49才男子にみられた下大静脈後 尿管のめずらしい一例を経験した.

2) 自験例は発生学的に Supracardinal Vein と Postcardinal Vein が共に残存したために発生したものと推 察される。

3）自験例は Harbach, Nielsen, Campbell and Anderson らの分類にみられない文献上新しい型に属すると思 われる.

4）合併症として, 腸回転異常を伴つていた.

本論文の要旨は昭和 47 年 3 月16日, 第 339 回日本泌尿 器科学会東京地方会で発表した。

\section{文献}

1) Berjian, R.A.: J. Am. Osteopath. Assoc., 66, 621, 1967. (臨泌, 25巻, 佐藤より引用)

2) Bitker, M.P.: J. d'Urol., 71, 851, 1965.

3) Brooks, R.E.: J. Urol., 88, 484, 1962.

4) Butler, E.G.: (8) 上り引用)

5) Campbell, G.D. and Anderson, J.C.: Australian and Newzealand jou. of Surgery., 35, 41, 1965.

6) Corbus, B.C., Estern, R.D. and Hunt, W.: J. Urol., 84, 67, 1960.

7) 藤井浩, 雀部 将, 荒木 徹: 泌要紀要, 12, 1422, 1966.

8) Gladstone, R.J.: J. Anat., 64, 70, 1929.
9) Graves, R.C. and Davidoff, L.M.: J. Urol., 8, 75, 1922.

10) Harbach, F.O.: N.Y.St.J.Med., 40, 800, 1940. (Young: Brit. J. Urol, 29, 上り引用)

11) Hochstetter, F.: Morphol. Jahrbuch., 20, 543, 1893. (Shih: J. Urol, 38, 上り引用)

12) Huntington, S.S. and McClure, C.F.: (20) よ り引用)

13) Kerschner, L.:（8）ょり引用）

14) 工藤 潔, 千野一郎, 町田豊平, 增田富士男, 小 林睦生, 佐藤 勝, 大石幸彦, 吉良正士, 南武 : 臨泌, 26, 589, 1972.

15）Lewis，F.T.:（8）ょり引用）

16) McClure, C.F.W.: Amer. Naturalist., 34, 185, 1900. (Shih: J, Urol, 38，ょり引用)

17) McClure, C.F. and Butler, E.G.：（8）ょり引 用)

18）水本竜助, 身吉隆雄, 福地 晋, 角田和男 : 日 泌尿会誌, 59, 86, 1968.

19）並木重吉, 入山盆四郎：日泌尿会誌，45，362, 1954.

20) Nielsen, P.B.: Acta. Radiol., 51, 179, 1959.

21) Pick, J.W. and Anson, B.J.: J. Urol., 43, 672, 1940.

22) Randall, A. and Campbell, E.W.: J. Urol., 34, 565, 1935.

23) Rathke, H.: (8) より引用)

24) Reagan, F.P. with Tribe, M.：（8）より引用）

25) Reagan, F.P. and Robinson, A.: (8) より引用)

26) Sabin, F.L.:（8）より引用）

27）清水圭三, 三矢英輔, 蔡行敛, 小幡浩司, 早川 常彦, 森田 幽: 手術, 20, 25, 1966.

28）山際義秀，白石祐逸，広田紀昭：臨皮泌，20, $845,1966$.

（1972年11月 7 日受付） 